\title{
CORPORATE SOCIAL RESPONSIBILITY (CSR) SEBAGAI INSTRUMEN HUKUM EKONOMI DI ERA GLOBALISASI
}

\author{
Nur Sulistyo B Ambarini \\ Fakultas Hukum Universitas Bengkulu \\ E-mail: ambarini_nur@yahoo.com.sg
}

\begin{abstract}
Globalization of the world have substantial influence the development of the state and the country of Indonesia. One of the globalization trends that influence the development of economic law in Indonesia is the Corporate Social Responsibility (CSR). Corporate Social Responsibility (CSR) is a concept in economic activity associated with the embodiment of the concept of Sustainable Development . CSR arrangements in legislation, are a reflection of the principle of government intervention. In this regard CSR as an instrument of economic laws is mandatory to become a tool for corporate or business entity for achieve sustainable development and environmentally sound. This is intended as an effort to provide protection to the community, environment and natural resources of the business practices that harm. In addition it also guarantees the performance of firms in the economy in a balanced way to achieve socio-economic welfare of society.
\end{abstract}

Keywords: Corporate Social Responsibility (CSR); Economic Law, Globalization.

\begin{abstract}
Abstrak
Globalisasi dunia mempunyai pengaruh cukup besar perkembangan kehidupan bangsa dan negara Indonesia. Salah satu trend globalisasi yang berpengaruh terhadap perkembangan hukum ekonomi di Indonesia adalah Tanggung Jawab Sosial Perusahaan Corporate Social Responsibility (CSR). Corporate Social Responsibility CSR merupakan suatu konsep dalam kegiatan ekonomi berkaitan dengan perwuj udan konsep Pembangunan Berkelanjutan (sustainable development). Pengaturan CSR dalam perundang-undangan, pada prinsipnya merupakan pencerminan asas campur tangan pemerintah. CSR sebagai instrumen hukum ekonomi bersifat wajib diharapkan dapat menjadi sarana bagi perusahaan atau entitas bisnis, dalam mewujudkan pembangunan berkelanjutan dan berwawasan lingkungan. Hal ini dimaksudkan sebagai upaya untuk memberikan perlindungan terhadap masyarakat, sumberdaya alam dan lingkungan dari praktek-praktek bisnis yang merugikan. Disamping itu juga menjamin kinerja perusahaan dalam perekonomian secara seimbang demi tercapainya kesejahteraan sosial ekonomi masyarakat.
\end{abstract}

Kata Kunci: Corporate Social Responsibility (CSR); Hukum Ekonomi, Globalisasi.

\section{Pendahuluan}

Globalisasi ditandai adanya keterbukaan dan kebebasan telah melanda dunia, mengakibatkan terjadinya perubahan dalam berbagai aspek kehidupan terutama di negara-negara berkembang. Gelombang globalisasi yang berkembang merambah seluruh dunia pada abad 21 ini mengandung harapan, peluang dan tantangan, yang tidak dapat dihindari tetapi harus diantisipasi dan dihadapi. Arus globalisasi yang menerapkan pendekatan 'pasar bebas' telah membawa pengaruh terhadap kehidupan ma- syarakat di banyak negara baik negara maju maupun negara berkembang termasuk Indonesia.

Pada era globalisasi telah banyak perubahan yang terjadi baik di tingkat regional, nasional maupun internasional. Menurut Soerjono Soekanto ${ }^{1}$ perubahan dalam kehidupan masyarakat adalah segala perubahan yang terjadi dalam institusi-institusi sosial yang mempengaruhi sistem sosialnya, termasuk di dalam-

\footnotetext{
1 Soerjono Soekanto, 1999, Pokok-pokok Sosiologi Hukum, J akarta: Raja Grafindo Persada, hlm. 12.
} 
nya nilai-nilai, sikap dan pola perilaku diantara kelompok-kelompok dalam masyarakat tersebut. Pengaruh globlisasi mengakibatkan terjadinya perubahan tata kehidupan masyarakat baik politik, ekonomi, sosial budaya, dan juga tata nilai hukum dan perundang-undangan serta berbagai kebijakan.

Implikasi paling dominan akibat arus globalisasi salah satunya adalah perubahan yang terjadi pada aspek hukum. Hal ini sejalan dengan yang dikemukakan Cerero sebagaimana adagium yang mengatakan "ubi societas ibi ius", dimana ada masyarakat, di situ ada hukum. Jadi hukum adalah bagian penting dari realitas kehidupan masyarakat dan hukum itu sendiri akan memberikan implikasi yang kuat pada pembaharuan yang sedang dilaksanakan dalam rangka membangun supremasi hukum. Akibat terjadi perubahan dalam berbagai kehidupan masyarakat, maka perubahan hukum sangat mendesak untuk dilakukan baik ditingkat nasional maupun regional. Perubahan hukum mencakup pembaruan dalam cara berpikir, tingkah laku, pola hidup yang sesuai dengan tuntutan zaman. Dengan kata lain, agenda reformasi hukum dalam menghadapi arus globalisasi mencakup reformasi kelembagaan (institusional reform), reformasi perundangundangan (instrumental reform) dan reformasi budaya hukum (cultur reform) ${ }^{2}$.

Pembangunan hukum tidak hanya tertuju pada aturan atau substansi hukum tetapi juga pada struktur atau kelembagaan hukum dan pada budaya hukum ${ }^{3}$. Arah pembangunan hukum sebagaimana dalam Undang-undang RI No. 17 Tahun 2007 tentang Rencana Pembangunan Jangka Panjang Nasional Tahun 2005-20254, antara lain: untuk mendukung terwujudnya pertumbuhan ekonomi yang berkelanjutan; mengatur permasalahan yang berkaitan dengan ekonomi, terutama dunia usaha dan dunia industri; serta menciptakan kepastian investasi,

\footnotetext{
2 Abdul Manan, 2005, Aspek-Aspek Pengubah Hukum. J akarta: Prenada Media, hlm. 60.

3 Satjipto Rahardjo. 1983, Hukum dan Perubahan Sosial. Bandung: Alumni, hlm. 231

4 Lihat Undang-Undang RI No.17 Tahun 2007 (IV.1. Arah Pembangunan Jangk Panjang Tahun 2005-2025: IV.1.2. E. Reformasi Hukum dan Birokrasi), hlm. 92.
}

terutama penegakan dan perlindungan hukum. Pembangunan hukum dilaksanakan melalui pembaruan materi hukum dengan tetap memperhatikan kemajemukan tatanan hukum yang berlaku. Pengaruh globalisasi sebagai upaya untuk meningkatkan kepastian dan perlindungan hukum, penegakan hukum dan HAM, kesadaran hukum, serta pelayanan hukum yang berintikan keadilan dan kebenaran, ketertiban dan kesejahteraan dalam rangka penyelenggaraan Negara yang makin tertib, teratur, lancar, serta berdaya saing global.

Menurut Satjipto Rahardjo, reformasi hukum adalah perombakan hukum secara mendasar yang mempunyai kualitas 'paradigmatik'. Reformasi hanya benar-benar berkualitas perombakan, apabila tidak terjatuh menjadi anarki. Oleh karena itu reformasi membutuhkan sasaran yang jelas ${ }^{5}$. Sementara itu pernyataan Mantan Menteri Kehakiman Kabinet Reformasi, Muladi, menyebutkan bahwa reformasi hukum ekonomi merupakan salah satu dari tiga skala prioritas di bidang hukum yang mendesak direalisasi. Dua bidang yang lain adalah hukum yang berkaitan dengan masalah-masalah politik dan hukum yang berkaitan dengan hak asasi manusia dan budaya. ${ }^{6}$

Menghadapi berlakunya WTO (World Trade Organization) dan terjadi perubahan pesat dalam perkembangan perekonomian global maupun regional, mau tidak mau Indonesia harus melakukan perubahan-perubahan di bidang hukum terkait dengan hubungan ekonomi antar Negara. Reformasi hukum ekonomi dilakukan karena pada kenyataanya hukum yang ada belum mampu menjawab berbagai persoalan yang muncul terkait dengan kegiatan ekonomi baik pada tingkat nasional maupun global. Untuk itu diperlukan hukum ekonomi yang lebih dinamis ${ }^{7}$, membuka kemungkinan untuk berbagai kebutuhan masyarakat, tidak hanya mendukung pembangunan

\footnotetext{
5 Satjipto Rahardjo. "Keluasan Reformasi Hukum". Kompas, 8 Mei 1998.

6 Adi Sulistiyono, 2007, Reformasi Hukum Ekonomi Indonesia. Surakarta: LPP dan UPT Penerbitan dan Pencetakan UNS (UNS Press), hlm. 3.

7 Sunaryati Hartono, 1982, Hukum Ekonomi Pembangunan Indonesia, Bandung: Bina Cipta, hlm. 169.
} 
ekonomi saja tetapi juga dengan tetap memelihara keadilan. Menurut Adi Sulistiyono ${ }^{8}$, diperlukan pendekatan ekonomi dalam pembangunan hukum ekonomi. Dengan pendekatan tersebut diharapkan reformasi hukum ekonomi menghasilkan tujuan: pertama, menciptakan suatu sistem hukum ekonomi 'kekeluargaan' atau 'kerakyatan' yang punya daya penangkal dalam menyaring masuknya unsur asing yang bertentangan dengan nilai Pancasila dan UUD Negara RI 1945; kedua, menciptakan kegiatan ekonomi yang efisien dan produktif; ketiga, menciptakan kepastian hukum di lingkungan penegak hukum dan birokrat, sehingga hukum ekonomi mempunyai daya prediktabilitas yang berguna bagi para pelaku bisnis; keempat, mendorong masyarakat agar gesit menangkap dan menggunakan peluang ekonomi dan sosial yang transparan; kelima, memperlancar pemerataan ekonomi; keenam, mampu menciptakan nasionalisme ekonomi; ketujuh, hukum ekonomi yang mampu mengikuti trend bisnis internasional.

Terkait dengan trend bisnis yang sedang berkembang, adalah konsep Tanggung J awab Sosial Perusahaan atau Corporate Social Responsibility (CSR). Dalam dunia usaha konsep CSR bukan merupakan hal baru. Beberapa perusahaan telah melaksanakan sebagai suatu tindakan sukarela dalam konteks pelaksanaan etika bisnis. Berkaitan dengan penerapan prinsip-prinsip etika dalam bisnis, menyangkut persoalan moralitas dari suatu keputusan dan aktivitas. Dalam pelaksanaan reformasi hukum ekonomi, hal ini telah menimbulkan pro dan kontra di berbagai kalangan terutama di kalangan bisnis. Hal ini disebabkan konsep Corporate Social Responsibility (CSR) telah menjadi instrumen hukum yang diatur sebagai salah satu materi dalam beberapa peraturan perundang-undangan yang berkaitan dengan bidang ekonomi. Selanjutnya dalam tulisan ini membahas persoalan mengenai peran Corporate Social Responsibility (CSR) atau tanggung jawab sosial perusahaan sebagai instrumen hukum ekonomi pada era globalisasi.

\footnotetext{
8 Adi Sulistiyono, op cit, hlm. 77.
}

\section{Pembahasan \\ Globalisasi dan Pembangunan Hukum Eko- nomi}

Arus globalisasi telah melanda dunia yang mengakibatkan terjadinya perubahan dalam berbagai aspek kehidupan terutama di negaranegara berkembang. Menurut Baharudin Darus, beberapa perubahan yang memerlukan payung hukum agar berjalan sebagaimana layaknya, adalah: (1) globalisasi informasi dan komunikasi sebagai akibat kemajuan teknologidan sarana/ prasarana informasi dengan jangkauan yang makin global, kecepatan tinggi dan kapasitas yang lebih besar untuk menyalurkan berbagai ragam informasi; (2) globalisasi ekonomi dan perdagangan bebas, globalisasi keuangan dan pemilikan kapital, globalisasi pasar, dan gerak lajunya perusahaan transnational corporation di berbagai negara; (3) globalisasi gaya hidup dan pola konsumsi, globalisasi budaya, globalisasi persepsi dan kesadaran yang mana produk-produk ini dipasarkan keseluruh dunia; (4) globalisasi media massa dan cetak serta media elektronik, yang akan membangun opini global melalui media canggih dan mutakhir; (5) globalisasi politik dan wawasan. Arus global ini masuk melalui isu antara lain demokrasi, HAM, lingkungan hidup, dan kesetaraan gender. .

Globalisasi ekonomi ditandai dengan lahirnya beberapa bentuk multinational agreement, yang berskala internasional yaitu GATTPU (General Agreement on Tariffs and Trade Putaran Uruguay), yang antara lain melahirkan WTO-World Trade Organization); dan yang berskala regional seperti NAFTA (North America Free Trade Association), AFTA (ASEAN Free Trade Agreement ), EEC (European Economic Community), APEC (Asia Pacific Economic Cooperation), CARICO (Caribian Community), CACM (Central American Common Market). Lahirnya kesepakatan GATT-PU (General Agreement on Tariffs and Trade - Putaran Uruguay) dan WTO (World Trade Organization) sebagai organisasi atau badan yang berfungsi menafsirkan dan menjabarkan isi perjanjian GATT-PU, memunculkan liberalisasi perdagangan dunia tanpa proteksi dan hambatan serta mempertinggi persaingan perdagangan antar pelaku ekonomi. 
Selain itu bagi negara-negara yang telah menandatangani kesepakatan tersebut berkewajiban untuk menyesuaikan hukum nasionalnya dengan ketentuan-ketentuan dalam GATT-PU. Dengan menandatangani kesepakatan GATT-PU dan menjadi anggota WTO (World Trade Organization), globalisasi ekonomi sangat berpengaruh pada bidang hukum di Indonesia. Semua negara yang telah menjadi anggota WTO dan menandatangani GATT-PU wajib menyesuaikan hukum nasionalnya dengan ketentuanketentuan yang terdapat dalam GATT-PU. Oleh karena itu konsekuensinya Indonesia juga perlu melakukan penyesuaian-penyesuaian dengan perkembangan yang terjadi secara internasional. Menurut Muladi, hukum nasional dalam era globalisasi disamping mengandung local characteristics, seperti ideologi bangsa, kondisi-kondisi manusia, alam dan tradisi bangsa, juga harus mengandung kecenderungan-kecenderungan internasional (international trend) yang diakui oleh masyarakat internasional yang beradab ${ }^{9}$.

Beberapa trend internasional berkenaan globalisasi ekonomi selain kesepakatan GATTPU yang mempengaruhi perkembangan hukum ekonomi di Indonesia antara lain adalah KTT Bumi mengenai "Lingkungan Hidup dan Pembangunan" (United Nations Conference on Environment and Development) tahun $1992 \mathrm{di}$ Rio de J aneiro. Konferensi Rio ini menghasilkan beberapa kesepakatan diantaranya "Deklarasi Rio" dan "Agenda 21" yang berisi prinsip-prinsip menyangkut pengelolaan lingkungan dan pembangunan, telah melahirkan suatu konsep "Pembangunan Berkelanjutan" (Sustainable Development). Pembangunan berkelanjutan didasarkan atas perlindungan lingkungan hidup, pembangunan ekonomi dan sosial yang dituangkan dalam 3 (tiga) dokumen yang secara hukum mengikat (legally binding) dan 3 (tiga) dokumen yang secara hukum tidak mengikat (non-legally binding).

Legally binding documents terdiri dari tiga konvensi yaitu Convention on Biological Diversity (CBD) atau Konvensi Keanekaragaman

\footnotetext{
9 Ibid.
}

Hayati; United Nations Convention on Climate Change (UNFCCC) atau Konvensi Kerangka PBB tentang Perubahan Iklim; Convention to Combat Desertification (CCD) atau Konvensi tentang Mengatasi Degradasi lahan. Sedangkan non- legally binding documents terdiri dari tiga kesepakatan, yaitu: Rio Declaration (Deklarasi Rio); Forest Principle (Authoritative Statement of Principles for a Global Concensus on Management, Conservation, and Sustainable Development of all Types of Forest) yang menyatakan pentingnya hutan bagi pembangunan ekonomi, penyerap karbon atmosfer, perlindungan keragaman hayati dan pengelolaan DAS; Agenda 21 (rencana komprehensif mengenai program pembangunan berkelanjutan ketika memasuki abad 21). Dalam implementasinya pasca KTT Rio, komitmen global tersebut belum menggembirakan. Pada tahun 2002 (26 Agustus6 september) di J ohannesburg- Afrika Selatan, PBB menyelenggarakan KTT pembangunan Berkelanjutan (World Summit on Sustainable Development/WSSD), yang disebut dengan Konferensi Rio+10. Deklarasi Johannesburg, menggarisbawahi bahwa pembangunan berkelanjutan mempunyai tiga pilar yaitu ekonomi, lingkungan hidup, dan sosial. Intinya pembangunan berkelanjutan adalah pembangunan ekonomi yang harus berwawasan lingkungan sekaligus mengusahakan pemerataan yang seadil-adilnya. Karenanya pembangunan yang dilakukan harus bersifat holistik agar terjadi sinergi ${ }^{10}$

Dalam reformasi hukum ekonomi di Indonesia faktor penting yang perlu diperhatikan adalah reformasi hukum ekonomi wajib mengacu pada hasil-hasil GATT-PU yang telah disepakati Indonesia; reformasi hukum ekonomi harus memberi perhatian pada persoalan ekonomi kerakyatan atau keadilan ekonomi sebagaimana diamanatkan Pancasila dan UndangUndang Dasar Negara RI 1945. Dalam Undangundang Nomor. 17 Tahun 2007 tentang Rencana Pembangunan Jangka Panjang Nasional Tahun 2005-2025 disebutkan bahwa untuk mewujudkan bangsa yang berdaya saing, pembangunan

\footnotetext{
10 Yusuf Wibisono, 2007, Membedah Konsep dan Aplikasi CSR (Corporate Social Responsibility), Gresik: Fascho Publising.
} 
nasional jangka panjang diantaranya diarahkan untuk memperkuat perekonomian domestik dengan orientasi dan berdaya saing global, perekonomian dikembangkan dengan memperkuat perekonomian domestik serta beorientasi dan berdaya saing global; untuk itu dilakukan transformasi bertahap dari perekonomian berbasis keunggulan komparatif sumber daya alam menjadi perekonomian yang berkeunggulan kompetetif; berlandaskan prinsip demokrasi ekonomi yang memperhatikan kepentingan nasional sehingga terjamin kesempatan berusaha dan bekerja bagi seluruh masyarakat dan mendorong tercapainya penanggulangan kemiskinan; Pengelolaan kebijakan perekonomian perlu memerhatikan secara cermat dinamika globalisasi, komitmen nasional di berbagai fora perjanjian ekonomi internasional, dan kepentingan nasional dengan mengutamakan kelompok lemah, serta menjaga kemandirian dan kedaulatan ekonomi bangsa.

Pembangunan ekonomi merupakan penggerak utama pembangunan nasional. Dalam pelaksanaannya pembangunan di bidang ekonomi harus secara menyeluruh dan terpadu dengan lainnya untuk saling mendukung dan memperkuat demi mencapai kemajuan bangsa. Bidang hukum merupakan salah satu bidang yang mempunyai hubungan timbal balik cukup erat dengan pembangunan ekonomi. Sebagaimana dikatakan Ismail Saleh ${ }^{11}$, ekonomi merupakan tulang punggung kesejahteraan masyarakat, namun tidak dapat disangkal bahwa hukum juga merupakan pranata yang pada akhirnya menentukan bagaimana kesejahteraan yang dicapai dapat dinikmati secara merata, bagaimana keadilan sosial dapat diwujudkan dalam kehidupan masyarakat, dan bagaimana ilmu pengetahuan dan teknologi dapat membawa kebahagiaan bagi rakyat banyak. Perkembangan dan pertumbuhan ekonomi sangat cepat dan kompleks, yang dapat menimbulkan berbagai hubungan hukum dalam aktivitas ekonomi atau bisnis. Baik dalam konteks lokal, nasional maupun internasional. Oleh sebab itu hukum juga harus mampu mengantisipasi dan

\footnotetext{
${ }^{11}$ Ismail Saleh, 1990, Hukum dan Ekonomi, J akarta: PT Gramedia Utama, hlm. XXVII.
}

mengikuti perkembangan dalam kegiatan ekonomi. Terlebih di era globalisasi dimana gelombang perubahan kehidupan termasuk bidang perekonomian sangat cepat terjadi. Untuk itu reformasi hukum menjadi sangat penting terutama dalam bidang hukum ekonomi. Hukum ekonomi adalah rangkaian perangkat peraturan yang mengatur kegiatan ekonomi yang dilakukan oleh pelaku ekonomi. Dari batasan tersebut dapat diurai beberapa unsur, yaitu: perangkat peraturan adalah serangkaian peraturan (dari undang-undang sampai peraturan pelaksaannya) yang secara substansial mengatur seluruh atau sebagian kegiatan ekonomi pada umumnya; kegiatan ekonomi yang paling utama adalah kegiatan produksi dan distribusi. Kegiatan produksi dan distribusi pada dasarnya berada dalam dua ranah bidang hukum utama, yaitu ranah hukum privat dan ranah hukum publik. ${ }^{12}$

Sejak era reformasi 1997, telah banyak peraturan perundang-undangan yang diterbitkan dan disempurnakan sesuai perkembangan arus globalisasi. Fungsi hukum yang diharapkan setelah diubah melalui peraturan perundangundangan, antara lain: pertama, standard of conduct, yakni menjadi ukuran tingkah laku dan kesamaan sikap yang harus ditaati oleh setiap orang dalam hidup bermasyarakat; kedua, as a tool of social engineering, yakni hukum harus dapat dijadikan alat untuk menuju kehidupan yang lebih baik sesuai dengan situasi dan kondisi perubahan zaman; ketiga, as a tool of justification, yakni hukum sebagai alat untuk menyatakan benarnya suatu tingkah laku yang hidup dan berkembang dalam masyarakat; keempat, as a tool of control, yakni sebagai alat untuk mengontrol pemikiran dan tingkah laku manusia agar mereka selalu terpelihara moralnya, tidak melakukan perbuatan yang melanggar hukum, norma susila, dan ajaran agama yang dipeluknya; kelima, rechtzeken heid yakni agar dalam setiap persoalan dan permasalahan yang terjadi dalam masyarakat

\footnotetext{
${ }^{12}$ Sri Redjeki Hartono, 2007, Hukum Ekonomi Indonesia. Malang: Bayumedia Publishing, hlm. 10.
} 
ada kepastian hukum untuk dijadikan pegangan oleh seluruh masyarakat ${ }^{13}$.

Mengacu pada kesepakatan internasional sebagai konsekuensi menjadi anggota WTO, demi menyesuaikan dengan perkembangan globalisasi ekonomi dan perdagangan bebas, berbagai peraturan perundang-undangan telah diterbitkan dan sempurnakan. Beberapa peraturan perundang-undangan yang diterbitkan dan yang disempurnakan terkait bidang ekonomi, diantaranya adalah Undang-undang-undang Nomor 4 Tahun 1982 tentang Lingkungan Hidup (UULH) diganti dengan Undang-undang Nomor. 23 Tahun 1997 tentang pengelolaan Lingkungan Hidup (UUPLH), kemudian diperbaharui lagi dengan Undang-undang Nomor 39 Tahun 2009 tentang Perlindungan dan Pengelolaan Lingkungan Hidup; Undang-undang Nomor 5 Tahun 1999 tentang Larangan Praktek Monopoli dan Persaingan Usaha Tidak Sehat; Undangundang Nomor 8 tahun 1999 tentang Perlindungan Konsumen; Undang-undang Nomor 1 tahun 1967 tentang PMA dan Undang-undang Nomor 6 Tahun 1968 tentang Penanaman Modal dalam Negeri (PMDN) yang telah dicabut dan diganti dengan Undang-undang Nomor. 25 Tahun 2007 tentang Penanaman Modal (UUPM); demikian pula Undang-undang Nomor 1 Tahun 1995 tentang Perseroan Terbatas diganti dengan Undang-undang Nomor 40 Tahun 2007 tentang Perseroan Terbatas (UUPT).

Perubahan perundangan terutama dengan disahkannya dua Undang-Undang tersebut terakhir yaitu Undang-Undang Penanaman Modal (UUPM) dan Undang-undang Nomor 40 Tahun 2007 tentang Perseroan Terbatas, telah menimbulkan kontroversial dalam masyarakat khusus kalangan dunia usaha. Pro dan kontra terhadap undang-undang tersebut dipicu dengan adanya Pasal 74 UUPT yang mewajibkan perusahaan yang berkaitan dengan sumberdaya alam untuk melakukan program Tanggung Jawab Sosial Perusahaan (Corporate Social Responsibility). Sebelumnya hal tersebut juga telah diatur dalam Pasal 15 Undang-undang Nomor 25 Tahun 2007 tentang Penanaman

\footnotetext{
${ }^{13}$ Abdul Manan, op.cit. hlm. 69.
}

Modal, yang mewajibkan perusahaan dan penanaman modal yang berkaitan dengan sumberdaya alam dan lingkungan hidup untuk melakukan program CSR. Kontroversi tersebut timbul karena kewajiban melakukan program CSR dianggap bertentangan dengan hakekat kegiatan suatu perusahaan. Tujuan perusahaan melaksanakan kegiatannya, pada hakekatnya adalah untuk mencari keuntungan yang sebesarbesarnya. Selain itu tanggung jawab sosial perusahaan merupakan kewajiban moral dan bersifat sukarela (voluntary).

\section{Corporate Social Responsibility (CSR) sebagai Instrumen Hukum Ekonomi}

Konsep tanggung jawab sosial perusahaan (Corporate Social Responsibility/ CSR) menurut The World Business Council for Sustainable Development (WBCSD) adalah "Continuing commitment by business to behave ethically and contribute to economic development while improving the quality of life the workforce and their families as well as of the local community dan society at large" (komitmen dunia usaha untuk terus menerus bertindak secara etis, beroperasi secara legal dan berkontribusi untuk peningkatan ekonomi, bersamaan dengan peningkatan kualitas hidup dari karyawan dan keluarganya sekaligus peningkatan kualitas komunitas lokal dan masyarakat secara lebih luas). Menurut Sudhamek AWS (Pendiri dan CEO Garuda Food), merumuskan tanggung jawab sosial perusahaan (Corporate Social Responsibility/CSR) sebagai strategi jangka panjang untuk menjaga keberlangsungan hidup perusahaan dan pemangku kepentingan.

Tanggung jawab sosial perusahaan atau CSR pada hakekatnya merupakan bentuk kontribusi suatu perusahaan, dengan tujuan akhir menempatkan entitas bisnis untuk ikut serta mewujudkan pembangunan berkelanjutan (sustainable development). Pembangunan berkelanjutan sebagaimana didefinisikan WCED (The World Commission on Environment and Development): "sustainable development is 'development that meets the needs of the present without compromising the ability of future generations to meet their own needs' 
(WCED 1987: 43). ${ }^{14}$ Pelaksanaan pembangunan suatu negara, tidak hanya menjadi tanggung jawab pemerintah. Dalam mewujudkan kesejahteraan sosial dan peningkatan kualitas hidup masyarakat, memerlukan partisipasi segenap lapisan masyarakat termasuk dunia usaha. Terkait dengan hal ini, dunia usaha berperan untuk mendorong pertumbuhan ekonomi dengan tetap mempertimbangkan faktor lingkungan. Untuk mewujudkan hal itu maka tanggung jawab sosial harus dilakukan pada sisi dalam (internal) entitas bisnis dan sisi luar (eksternal) perusahaan. Berdasarkan pokok-pokok pikiran dalam The Handbook for Corporate Action, yang diterbitkan International Union for Conservation on Nature (IUCN) tahun 2002, perwujudan tanggung jawab sosial perusahaan paling sedikit memenuhi empat bentuk yaitu mewujudkan Good Corporate Governance; pengembangan masyarakat; berpartisipasi dalam pembangunan berkelanjutan; membina hubungan dengan masyarakat ${ }^{15}$.

Menurut Satjipto Raharjo, secara sosiologis hubungan antara industri dan lingkungan sebagai perwujudan tanggung jawab sosial perusahaan adalah merupakan pola interaksi yang wajar. Dalam perspektif manajemen berwawasan lingkungan, maka tanggung jawab sosial ini diinternalisasikan ke dalam proses penyusunan planning, budged, strategi dan penyiapan sistem informasinya. Sebab dalam kacamata manajemen ekonomi konvensional faktor tanggung jawab sosial terhadap lingkungan masih sebagai faktor luar perusahaaan.

Konsep tanggung jawab sosial perusahaan (CSR/Corporate Social Responcibility) melibatkan tanggung jawab kemitraan antara pemerintah, lembaga sumberdaya komunitas dan komunitas setempat (lokal). Benny Sutrisno (Presdir PT. Apac Inti Corpora), mengartikan CSR (Corporate Social Responcibility) sebagian"budi pekerti" perusahaan. Artinya, CSR mewujud dalam semua aspek kegiatan per-

\footnotetext{
${ }^{14}$ Susan Baker, Sustainable Development. New York: Routledge, Reprinted 2007, hlm. 20.

15 Hadi Sudharto P dan FX. Adji Samekto, 2007, Dimensi Lingkungan Dalam Bisnis: Tanggung Jawab Sosial Perusahaan Pada Lingkungan. Semarang: Badan Penerbit UNDIP, hlm127-139.
}

usahaan. Kemitraan yang berkeadilan dalam mata rantai nilai bisnis dipandang sebagai salah satu bentuk CSR pada aspek ekonomi. Pada aspek lingkungan, CSR mewujud antara lain pada analisis dan antisipasi dampak lingkungan secara bertanggungjawab. Disisi etika, CSR bersifat sukarela, tapi terkait dampak lingkungan CSR bersifat memaksa, diatur hukum ${ }^{16}$.

Corporate Social Responsibility (CSR) merupakan trend global yang digunakan sebagai alat bersaing perusahaan dalam bisnis modern. CSR dapat menjadi strategi bisnis perusahaan untuk meningkatkan daya saing dan mengangkat citra perusahaan sekaligus sebagai keunggulan kompetetif yang sulit ditiru. Okti Damayanti ${ }^{17}$ (Unilever peduli Foundation), menegaskan bahwa CSR (Corporate Social Responsibility) didefinisikan sebagai cara berbisnis. Semua cakupan kegiatan bisnis harus mempunyai dampak positif bagi masyarakat. Sedangkan menurut Mulyadi (Pengamat CSR UGM) CSR tetap mengandung motif tertentu. ${ }^{18}$ Motif-motif tersebut diantaranya menjaga keamanan fasilitas produksi, motif mematuhi kesepakatan kontrak kerja, dan motif moral untuk memberikan pelayanan sosial pada masyarakat lokal. Secara normatif, idealnya perusahaan seharusnya berusaha memberdayakan masyarakat lokal dan meningkatkan kesejahteraan mereka. Dan sekalipun masih sedikit, tapi beberapa perusahaan sudah banyak yang melakukan CSR atas motif moral.

Sebagai salah satu pilar Good Corporate Governance (GCG), pelaksanaan Corporate Social Responsibility (CSR) merupakan hal yang penting yang harus dilakukan oleh perusahaan. CSR merupakan bentuk pertanggungjawaban sosial perusahaan kepada stakeholders sudah menjadi tuntutan jaman ditengah dunia bisnis yang sudah berubah. Pandangan klasik menyatakan perusahaan sebagai institusi bisnis mempunyai tujuan utama menciptakan keuntungan (profit oriented) bagi pemegang saham

\footnotetext{
${ }^{16}$ Nur Hidayati, Menyoal Budi Pekerti Perusahaan, Kompas, 18 J uli 2008.

17 Deni Arisandy, Demi Business Sustainable, Majalah Manajemen Risiko Stabilitas, edisi No. 23-oktober 2007 hlm. 15.

18 Loc. cit.
} 
(shareholders). Namun pandangan tersebut telah berubah, dan perusahaan yang ingin bertahan pada era global harus mengubah paradigma tanggungjawabnya dari shareholders menjadi tanggung jawab sosial kepada stakeholders. ${ }^{19}$ Menurut Kenneth Andrews, perubahan paradigma shareholders menjadi paradima stakeholders terhadap perusahaan dalam mengelola usahanya tidak terlepas dari 3 (tiga) aspek yaitu self-interest adalah secara personal akan memberikan stimulus kepada para eksekutif perusahaan yang akan mengarahkan sumber daya bisnis untuk mengatasi masalah sosial; moralitas adalah nilai etika yang mengatur aktivitas perusahaan; refikasi perusahaan adalah nilai moral yang diyakini oleh perusahaan. ${ }^{20}$

Stakeholders, menurut definisi RE Freedman (1984) adalah "any group or individual who can affect or is acffected by the achievement of the organization's objective." Secara bebas diterjemahkan sebagai kelompok atau individu yang dapat mempengaruhi dan atau dipengaruhi oleh suatu pencapaian tertentu. ${ }^{21}$ Stakeholders dapat diartikan sebagai seseorang atau sekelompok orang yang memiliki satu atau lebih kepentingan (stake) yang berbeda dalam suatu perusahaan. Dalam hal ini stakeholders dapat terpengaruh dan juga mempengaruhi tindakan, keputusan, kebijakan atau praktikpraktik yang dilakukan perusahaan. Kepentingan (stake) seseorang atau sekelompok orang terhadap suatu perusahaan tersebut dapat muncul karena adanya hak hukum (legal right )dan hal moral (moral right). Menurut Sonny Keraf (1998), dalam pendekatan stakeholders perusahaan (kegiatan bisnis) dituntut dan menuntut dirinya untuk menjamin stakeholders yang terdiri dari dua kelompok yaitu kelompok primer dan sekunder. Kelompok primer (pemilik modal/saham, kreditor, karyawan, pemasok, konsumen, penyalur, pesaing atau rekanan); Kelompok sekunder (pemerintah setempat,

\footnotetext{
${ }^{19}$ Riza Irvan, Tanggungjawab Sosial: Agenda Bisnis Global, Majalah Manajemen Usahawan Indonesia No. 11/XXIX/ Nopember 2000, hlm. 15.

20 Isa Wahyudi dan Busyra Azheri, 2008, Corporate Social Responsibility: Prinsip, Pengaturan dan Implikasi, Malang: In-Trans Publishing, Cet. 1, hlm. 80

${ }^{21} \mathrm{lbid}, \mathrm{hlm} .73$.
}

atau asing, kelompok sosial, media massa, masyarakat setempat atau umum).

John Elkington dalam bukunya "Cannibals with Fork, the Triple Bottom Line of Twetieth Century Business" mengembangkan konsep "Triple Bottom Line" dalam istilah economic prosperity, environmental quality dan social justice. Pandangan John Elkington menyatakan bahwa jika perusahaan ingin mempertahankan berkelanjutan hidupnya haruslah memperhatikan "3P" (Profit, People, Planet). Selain mengejar keuntungan (profit), perusahaan juga harus memperhatikan dan terlibat pada pemenuhan kesejahteraan masyarakat (people) dan berkontribusi dalam menjaga kelestarian lingkungan hidup (planet) ${ }^{22}$. Dengan kata lain aspek ekonomi yang direfleksikan dalam kondisi keuangan saja, juga harus memperhatikan aspek sosial dan lingkungannya. Ketiga hal tersebut (ekonomi, sosial dan lingkungan hidup) pada dasarnya merupakan pilar dari keberhasilan untuk mewujudkan pembangunan berkelanjutan.

Keuntungan (profit) merupakan tujuan utama perusahaan dalam melakukan kegiatan bisnis. Hal ini harus dilakukan untuk menjaga keberlanjutan ekonomi perusahaan. Keberlanjutan (sustainability) ekonomi perusahaan perlu diperhatikan karena merupakan dasar bagi perusahaan untuk menjaga keberlanjutan sosial dan keberlanjutan lingkungan. ${ }^{23}$ Selain itu sebagai konsekuensi tanggung jawab ekonomi, perusahaan harus memenuhi tanggungjawabnya terhadap stakeholders primer. Stakeholders primer dalam hal ini pemilik modal atau pemegang saham, karyawan, kreditor, mempunyai hak hukum (legal right) terhadap perusahaan berdasarkan perjanjian yang telah disepakati atau peratuan yang berlaku. Selain mempunyai tanggung jawab ekonomi, perusahaan juga mempunyai tanggung jawab legal terhadap kelompok ini. Stakeholders primer merupakan ujung tombak berlangsungnya

\footnotetext{
${ }^{22}$ Yusuf Wibisono, 2007, Membedah Konsep dan aplikasi CSR (Corporate Social Resposibility). Gresik: Fasco Publising, hlm. 32.

23 Gunawan Wijaya dan Yeremia Ardi Pratama, 2008, Risiko Hukum dan Bisnis Perusahaan Tanpa CSR, Jakarta: Penerbit ForumSahabat, Cet. 1, hlm. 45
} 
kegiatan perusahaan. Oleh karena itu penting dan wajib diperhatikan sebab menyangkut hidup dan mati serta keberhasilan perusahaan.

Keberhasilan perusahaan memperoleh keuntungan, tidak hanya untuk memenuhi kepentingan stakeholders primer. Di sisi lain perusahaan juga harus memperhatikan kepentingan kelompok stakeholders sekunder. Kelompok ini meliputi pemerintah, institusi sipil, LSM, Pers, pesaing usaha, asosiasi pengusaha dan masyarakat pada umumnya. Kelompok ini mempunyai kepentingan dan berpengaruh terhadap perusahaan, terutama berkaitan dengan reputasi atau citra perusahaan. Secara langsung kelompok ini tidak mempunyai kepentingan dengan kegiatan inti perusahaan. Tetapi kepentingan kelompok ini atas perusahaan timbul karena hak moral (moral right).

Masyarakat (people) secara umum merupakan kelompok yang dapat memperoleh manfaat sekaligus dampak dari kegiatan yang dilakukan oleh perusahaan. Di satu sisi masyarakat adalah konsumen atau pengguna produk dari perusahaan. Di sisi lain terutama masyarakat setempat (lokal) tempat dimana perusahaan beroperasi, juga menjadi penerima dampak baik dampak positif maupun negatif. Dampak positif diharapkan dapat memberikan kontribusi bagi kemajuan dan kesejahteraan masyarakat setempat. Namun dampak negatif seringkali menimbulkan gejolak yang dapat mempengaruhi image atau penilaian terhadap kinerja perusahaan. Kegiatan perusahaan dapat berpengaruh dan dipengaruhi oleh masyarakat yang ada disekitar lokasi perusahaan. Oleh karena itu perusahaan juga harus menjalin dan menjaga hubungan baik dengan masyarakat setempat. Dalam hal ini perusahaan dapat melaksanakan tanggung jawab sosialnya (Corporate Social Responsibility/CSR) terhadap komunitas disekitarnya. Dengan adanya perusahaan diharapkan dapat membantu meningkatkan kesejahteraan masyarakat. Misalnya dengan perekrutan tenaga kerja, sehingga dapat meningkatkan pendapatan masyarakat, sekaligus mengatasi persoalan pengangguran. Dapat juga dengan kegiatan lain yang bersifat produktif ataupun bertujuan meningkatkan kualitas hidup masyarakat dibidang pendidikan, kesehatan dan sebagainya. Dengan demikian keberlanjutan sosial masyarakat dapat terjaga. Hal ini tidak hanya menguntungkan bagi masyarakat, tetapi juga bagi perusahaan. Dengan kondisi sosial ekonomi masyarakat yang kondusif, maka kegiatan perusahaan dapat berlangsung aman dan nyaman serta berkelanjutan.

Beroperasinya perusahaan di suatu lokasi mempunyai konsekuensi terhadap masyarakat dan lingkungan disekitarnya. Selain dampak sosial, juga secara ekologi kegiatan perusahaan dapat menimbulkan permasalahan terhadap sumber daya alam dan lingkungan hidup di sekitarnya. Aktivitas perusahaan cenderung dianggap sebagai penyebab global warming dan masalah-masalah lingkungan hidup lain yang terjadi akhir-akhir ini. Lingkungan yang baik dan sehat dapat mendukung kelancaran kegiatan perusahaan. K. Bertens (2000) menyebutkan bahwa alam dan lingkungan hidup (planet) juga berkedudukan sebagai stakeholders. Oleh karena itu menjadi kewajiban perusahaan untuk menjaga kelestarian lingkungan hidup disekitarnya. Persoalan kelestarian alam dan lingkungan hidup merupakan hal penting bagi perusahaan, terutama yang bergerak di bidang sumber daya alam. Eksploitasi yang tidak terkendali akan menyebabkan kerusakan/pencemaran dan kelangkaan sumber daya alam. Hal demikian dapat mengganggu keberlanjutan lingkungan. Pada akhirnya dapat berakibat mengganggu keberlangsungan kegiatan perusahaan yang bersangkutan.

Perhatian terhadap masyarakat dan lingkungan hidup dapat merupakan bentuk tanggung jawab sosial perusahaan. Dengan melaksanakan tanggung jawab sosial, perusahaan dapat terbantu dalam menjaga dan meningkatkan daya saing melalui citra perusahaan di tengah-tengah masyarakat. Secara tidak langsung hal ini akan memberikan keuntungan bagi perusahaan. Reputasi atau citra perusahaan yang baik dapat memberikan image yang baik terhadap produk yang dihasilkan. Imbasnya akan memberikan keuntungan finansial, karena produknya akan dapat diterima baik oleh konsumen baik lokal maupun mancanegara. 
Kesadaran perusahaan melaksanakan tanggung jawab sosialnya, sekaligus dapat membantu perusahaan untuk melaksanakan tanggung jawab legal dari perusahaan. Tanggung jawab legal merupakan tanggungjawab perusahaan sebagai badan hukum terhadap pemerintah setempat untuk mematuhi peraturan hukum yang berlaku. Secara hukum administrasi, perusahaan harus melaksanakan ketentuan-ketentuan hukum yang berlaku. Seperti misalnya ketentuan yang ditetapkan dalam Undang-Undang Perlindungan dan Pengelolaan Lingkungan Hidup berkaitan dengan Baku Mutu Lingkungan, AMDAL, pembuangan limbah; Ketentuan Undang-Undang Ketenagakerjaan, Undang-Undang Perlindungan Konsumen dan sebagainya. Demikian juga terhadap pihak lain untuk melaksanakan hak dan kewajiban yang telah disepakati dalam perjanjian; maupun terhadap tuntutan pengadilan.

Ditinjau dari sisi regulasi, pada dasarnya implementasi Corporate Social Responcibility (CSR) sudah menjadi komitmen pemerintah. Pada perusahaan BUMN dengan Program Kemitraan Bina Lingkungan (PKBL), merupakan perwujudan CSR yang bersifat wajib. Meski sudah banyak perusahaan di Indonesia melaksanakan CSR, namun masih bersifat insidental dan belum terintegrasi. Terdapat tiga tingkatan orientasi pelaksanaan CSR yaitu charity, parsial dan berorientasi pada peningkatan daya saing. ${ }^{24}$

Terlepas dari perdebatan pro dan kontra yang berkembang dalam masyarakat bisnis, pengaturan CSR dalam Pasal 74 Undang-Undang No. 40 Tahun 2007 tentang Perseroan Terbatas dan Pasal 15 Undang-Undang No. 25 Tahun 2007 tentang Penanaman Modal adalah merupakan satu bentuk progresivitas dalam reformasi hukum khususnya dalam pembangunan hukum ekonomi. Pengaturan CSR dalam undang-undang tersebut sebagai bentuk campur tangan pemerintah yang mengandung nilai-nilai untuk melindungi berbagai aspek kehidupan kemanu$\operatorname{siaan}^{25}$. Khususnya aspek sosial, ekonomi dan

\footnotetext{
${ }^{24}$ Drajad Kurniawan, Masíh Jauh dari Panggang Api, Majalah "Stabilitas" Edisi No. 23- Oktober 2007, hlm. 19.

${ }^{25}$ Sri Redjeki Hartono, op.cit, hlm. 13, menyebutkan: Asasasas utama dari hukum ekonomi yang bersumber dari
}

lingkungan dalam kegiatan ekonomi yang dilakukan pelaku ekonomi (perusahaan). Campur tangan pemerintah diperlukan pada dasarnya dalam rangka menjaga keseimbangan kepentingan semua pihak di dalam masyarakat. Dalam hal ini adalah kepentingan perusahaan, masyarakat dan lingkungan hidup. Terdapat hubungan saling membutuhkan antara perusahaan sebagai produsen dan masyarakat sebagai konsumen. Demikian pula dengan alam dan lingkungan serta masyarakat disekitar tempat perusahaan beroperasi.

Penggantian kedua Undang-Undang tersebut tidak hanya sekedar mengganti, menyesuaikan dengan trend global, tetapi akan merupakan perombakan hukum ekonomi secara mendasar yang mempunyai kualitas 'paradigmatik'. Selain menyelaraskan kepentingan nasional dengan aturan-aturan internasional dalam GATT-PU, pengaturan CSR dalam peraturan perundang-undangan dan penerapannya akan menciptakan keadilan ekonomi bagi masyarakat. Perubahan Undang-Undang Perseroan Terbatas dan Undang-Undang Penanaman Modal dengan penambahan materi CSR di dalamnya, diharapkan dapat menjadi landasan dan mampu memandu pelaku ekonomi di Indonesia, dalam menjalan aktivitas bisnis baik dalam skala nasional maupun global. Meski dalam Pasal 74 Undang-Undang Perseroan Terbatas (UUPT) dan Pasal 15 Undang-Undang Penanaman Modal (UUPM) hanya mewajibkan perusahaan dan penanaman modal yang berkaitan dengan sumberdaya alam dan lingkungan hidup untuk melakukan program CSR, tetapi dalam implementasinya akan lebih progresif tidak hanya terpaku pada apa yang tercantum dalam ketentuan peraturan perundang-undangan tersebut.

Sebagaimana dalam paradigma hukum progresif" ${ }^{26}$, bahwa "Hukum adalah untuk Manusia", yang menolak untuk mempertahankan keadaan status quo dalam cara berhukum se-

asas-asas hukum publik yang patut diperhatikan antara lain: asas keseimbangan kepentingan, asas pengawasan public, dan asas campur tangan Negara terhadap kegiatan ekonomi.

26 Satjipto Rahardjo, 2007, Biarkan Hukum Mengalir. Yakarta: Penerbit Buku Kompas, hlm. 138. 
perti cara positivistik, normatif dan legalistik, yang harus bekerja dengan rumusan-rumusan hukum alam perundang-undangan. Hukum progresif berpegang pada paradigma "Hukum untuk Manusia". Manusia disini merupakan simbol bagi kenyataan dan dinamika kehidupan. Hukum itu memandu dan melayani masyarakat. Dengan demikian diperlukan keseimbangan antara "statika" dan "dinamika", antara peraturan dan 'jalan- yang-terbuka'. ${ }^{27}$

Mengacu pada paradigma tersebut dan berpedoman pada nilai-nilai Pancasila, yaitu sistem hukum yang tidak mengandalkan pada rule of law tapi lebih menaruh perhatian pada rule of moral atau rule of justice ${ }^{28}$. Penerapan CSR yang pada awalnya merupakan instrumen dalam etika bisnis yang bersifat sukarela. Sekarang menjadi instrumen hukum yang bersifat wajib, tetapi tidak mengurangi essensi dari konsep CSR itu sendiri. Diharapkan dalam penerapan selanjutnya tidak hanya merupakan reformasi kelembagaan (institusional reform), dan reformasi perundang-undangan (instrumental reform, tetapi juga merupakan reformasi budaya hukum (cultur reform) terutama bagi para pelaku ekonomi dalam dunia bisnis. Tidak hanya kegiatan ekonomi yang terkait dengan sumber daya alam oleh pelaku usaha besar, tetapi juga pelaku ekonomi dalam skala UMKM (Usaha Mikro, Kecil dan Menengah), serta masyarakat pada umumnya. Dengan demikian penerapan Corporate Social Responsibility (CSR) sebagai instrumen hukum ekonomi, dapat menjadi media pengarusutamaan konsep pembangunan berkelanjutan dalam kegiatan ekonomi.

\section{Penutup \\ Simpulan}

Berdasarkan uraian dalam pembahasan dapat disimpulkan bahwa dalam mengantisipasi dan menyesuaikan perkembangan di era globalisasi, reformasi hukum ekonomi dilakukan

\footnotetext{
${ }^{27}$ Satjipto Rahardjo, 2005, Penafsiran Hukum yang Progresif (Prawacana) dalam Buku Semiotika Hukum dari Dekonstruksi Teks menuju Progresivitas Makna (Anthon Fredi Susanta), Bandung: Refika Aditama, hlm.14.

${ }^{28}$ Satjipto Rahardjo, dikutip oleh Adi Sulistiyono, 2007, Reformasi Hukum Ekonomi Indonesia, Surakarta: Penerit UNS, hlm. 74
}

dengan beberapa perubahan, penyempurnaan maupun penyusunan berbagai peraturan perundang-undangan dalam bidang ekonomi. Pengaturan Corporate Social Responsibility (CSR) dalam peraturan perundang-undangan merupakan pengejawantahan asas-asas utama hukum ekonomi. Pengaturan Corporate Social Responsibility (CSR) dalam Undang-Undang No.25 Tahun 2007 dan Undang-Undang No. 40 Tahun 2007, merupakan pencerminan asas campur tangan pemerintah, asas keseimbangan kepentingan, pengawasan publik, dalam kegiatan ekonomi. Dalam hal ini CSR sebagai instrumen hukum ekonomi bersifat wajib yang ditujukan khusus kepada kegiatan usaha yang terkait langsung dengan sumber daya alam dan lingkungan oleh pelaku ekonomi dalam bentuk perseroan. Ini dimaksudkan untuk memberikan perlindungan terhadap masyarakat, sumberdaya alam dan lingkungan dari praktek-praktek bisnis yang merugikan. Menjamin kinerja perusahaan dalam perekonomian secara seimbang demi tercapainya kesejahteraan sosial ekonomi masyarakat. Tetapi sebagai instrumen ekonomi yang bersifat sukarela, Corporate Social Responsibility (CSR) tetap merupakan suatu hal yang harus dilakukan oleh setiap pelaku ekonomi (perusahaan) yang melaksanakan kegiatan usaha dalam kerangka pelaksanaan etika bisnis. Selain itu dalam pelaksanaan pembangunan ekonomi yang berkelanjutan dan berwawasn lingkungan, seharusnya Corporate Social Responcibility (CSR) tidak hanya dilaksanakan oleh kegiatan usaha (perusahaan) dalam skala besar. Pelaku usaha dalam skala kecil dan menengah pun perlu mengusahakan pelaksanaan Corporate Social Responsibility (CSR) sebagai bentuk kepedulian terhadap lingkungan disekitarnya.

\section{DAFTAR PUSTAKA}

Arisandy, Deni. "Demi Business Sustainable". Majalah Manajemen Risiko Stabilitas, edisi No. 23. Oktober 2007;

Baker, Susan. 2007. Sustainable Development. New York: Routledge; 
Hartono, Sunaryati. 1982. Hukum Ekonomi Pembangunan Indonesia. Bandung: Bina Cipta;

Hartono, Sri Redjeki. 2007. Hukum Ekonomi Indonesia. Malang: Bayumedia Publishing;

Hidayati, Nur. "Menyoal Budi Pekerti Perusahaan". Kompas. 18 J uli 2008;

Irvan, Riza. "Tanggungjawab Sosial: Agenda Bisnis Global", Majalah Manajemen Usahawan Indonesia No. 11/ XXIX/ Nopember 2000;

Kurniawan, Drajad. "Masíh J auh dari Panggang Api", Majalah Stabilitas Edisi No. 23Oktober 2007;

Manan, Abdul. 2005. Aspek-Aspek Pengubah Hukum. Jakarta: Prenada Media;

Rahardjo, Satjipto. 1983. Hukum dan Perubahan Sosial. Bandung: Alumni;

"Keluasan Reformasi Hukum". Kompas. 8 Mei 1998;

2007. Biarkan Hukum Mengalir. Yakarta: Penerbit Buku Kompas;

Saleh, Ismail. 1990. Hukum dan Ekonomi. J akarta: PT Gramedia Utama;

Soekanto, Soerjono. 1999. Pokok-pokok Sosiologi Hukum. Jakarta: Raja Grafindo Persada;

Sudharto, Hadi P dan FX. Adji Samekto. 2007. Dimensi Lingkungan Dalam Bisnis: Tanggung J awab Sosial Perusahaan Pada Lingkungan. Semarang: Badan Penerbit UNDIP;

Sulistiyono, Adi. 2007. Reformasi Hukum Ekonomi Indonesia. Surakarta: LPP dan UPT Penerbitan dan Pencetakan UNS (UNS Press);

Wahyudi, Isa dan Busyra Azheri. 2008. Corporate Social Responsibility: Prinsip. Pengaturan dan Implikasi, Cet. 1. Malang: In-Trans Publishing;

Wibisono, Yusuf. 2007. Membedah Konsep dan aplikasi CSR (Corporate Social Resposibility). Gresik: Fasco Publising;

Wijaya, Gunawan dan Yeremia Ardi Pratama. 2008. Risiko Hukum dan Bisnis Perusahaan Tanpa CSR. Cet. 1. Jakarta: Penerbit ForumSahabat;

Susanta, Anthon Fredi. 2005. Semiotika Hukum dari Dekonstruksi Teks menuju Progresivitas Makna. Bandung: Refika Aditama. 